\title{
針状ムライトからなる多孔質セラミックスシートの作製とその特性
}

勝 木 宏 昭・古田祥知子・一ノ瀬弘道 - 中尾 浩 (佐賀県嘿業試験場ファインセラミックス部, 844 佐賀県西松浦郡有田町中部 3100-5)

\section{Preparation and Some Properties of Porous Ceramics Sheet Composed of Needle-Like Mullite}

\author{
Hiroaki KATSUKI, Sachiko FURUTA, Hiromichi ICHINOSE and Hiroshi NAKAO \\ (Ceramics Research Institute of Saga Prefectural Goverment, \\ (3100-5, Chubu, Arita-machi, Nishimatsuura-gun, Sagar 844
}

\begin{abstract}
Needle-like mullite was prepared from New Zealand kaolin at temperatures from $1300^{\circ}$ to $1700^{\circ} \mathrm{C}$, and some properties of a porous ceramics sheet composed of needle-like mullite produced by leaching out the silica glass from the fired kaolin were examined. The fine needle-like mullite began to grow at $1500^{\circ} \mathrm{C}$ and crystals 10 to $20 \mu \mathrm{m}$ long and 1 to $2 \mu \mathrm{m}$ thickness were obtained above $1650^{\circ} \mathrm{C}$. The growth direction was identified to be [001] of mullite. Most of the alumina component contained in the raw material was converted into mullite above $1650^{\circ} \mathrm{C}$, and the product was composed of 59 to 60 wt\% of mullite, 39 to 40 wt\% of glass and approximately 0.6 wt\% of corundum. Leaching out 39.3 wt\% of glass from the kaolin fired at $1650^{\circ} \mathrm{C}$ provided a porous sheet with the porosity approximately $60 \%$ and the pore diameter of 0.5 to $0.6 \mu \mathrm{m}$. With thoroughly leaching out the glass, the ratio of $\mathrm{Al}_{2} \mathrm{O}_{3} / \mathrm{SiO}_{2}$ and the apparent density of the porous sheet approached those of the theoretical mullite. Furthermore, the specific surface area of the porous sheet increased with increasing amount of glass leached and did not decrease by reheating in the temperature range from $1200^{\circ}$ to $1650^{\circ} \mathrm{C}$.
\end{abstract}

[Received May 16, 1988 ; Accepted July 22, 1988]

Key-words : Needle-like mullite, New Zealand kaolin, Porous ceramics sheet, Acid treatment, Porosity, Specific surface area

\section{1. 緒 言}

ムライトの針状結晶及びウイスカーは，セラミックス の䩚性及び高温強度を改善する材料として最近注目され ている.これらの結晶の合成法としては, $\mathrm{SiO}_{2}, \mathrm{Al}$, $\mathrm{Al}_{2} \mathrm{~S}_{3}$ 混合物の不活性雾囲気中での熱処理 ${ }^{11}$, 混合アル コキシドの水熱処理 ${ }^{2) ~ 3)}, \mathrm{AlF}_{3}-\mathrm{SiO}_{2}$ キセロゲルあるい は $\mathrm{Si}\left(\mathrm{OC}_{2} \mathrm{H}_{5}\right)_{4}$ と $\mathrm{Al}\left(\mathrm{NO}_{3}\right)_{3} \cdot 9 \mathrm{H}_{2} \mathrm{O}$ より調製したキセロ ゲルの熱処理4)等がこれまでに報告されている.一方, 陶磁器, 耐火物等の原料であるカオリン, シリマナイト などのアルミナーシリカ系粘土鉱物を $1200^{\circ} \mathrm{C}$ 以上で焼 成すると,マトリックスのガラス中に長さ数〜数 $10 \mu \mathrm{m}$, 太さ $0.5 \sim 3 \mu \mathrm{m}$ の針状ムライトが生成することが古く より知られている ${ }^{5) ~ 8)}$. この針状ムライトの周囲に共存 するガラス相を十分に溶出すると, 多数の針状ムライト が密に交錯した組織となる ${ }^{9}$ が, 多孔材料の見地からの 研究はこれまでに報告されていない，安価な天然粘土鉱 物を原料として, 針状組織からなるムライト多孔体が調 製できれば，新しい機能を持ったムライト材料の開発に つながるものと考えられる.

したがって本研究では, 安価で成形性が良く, また不 純物含有量が少ないニュージーランドカオリンを原料と して, 針状ムライトの生成条件について検討し, ガラス
相を溶出して得られる針状ムライト組織を有する多孔体 の諸性状について調べた。

\section{2. 実験方法}

\section{1 針状么ライトの生成と多孔組織体の調製}

原料には市販のニュージーランドカオリン粉末 (Ig. loss : 13.79, $\mathrm{SiO}_{2}: 50.07, \mathrm{Al}_{2} \mathrm{O}_{3}: 35.76, \mathrm{Fe}_{2} \mathrm{O}_{3}: 0.26$, $\mathrm{TiO}_{2}: 0.07, \mathrm{CaO}: \mathrm{Tr}$., $\mathrm{MgO}: 0.08, \mathrm{Na}_{2} \mathrm{O}: 0.07$, $\mathrm{K}_{2} \mathrm{O}: 0.01 \mathrm{wt} \%$, 平均粒径: 約 $\left.0.5 \mu \mathrm{m}\right)$ を用いた. バ インダーとしてメチルセルロースを $10 \mathrm{wt} \%$ 加え, 更に 純水を添加して十分に混合して粘土を調製した．その後 押出し成形機により幅 50 , 厚さ $0.25 \mathrm{~mm}$ のシートを作 製した. シートの乾燥は $100^{\circ} \sim 200^{\circ} \mathrm{C}$ で数分間行った。 このシートを長さ 30 , 幅 $15 \mathrm{~mm}$ に切り, $1300^{\circ}$ $1700^{\circ} \mathrm{C}$ で $1 \sim 10$ 時間大気中で焼成した. 昇温速度, 降 温速度はそれぞれ $2.2,5.7^{\circ} \mathrm{C} / \mathrm{min}$ とした。原料及び多 孔体の化学組成は, 蛍光 X 線 (理学電機製, 3070 型) により調べた. また各温度で焼成した試料中のムライト,

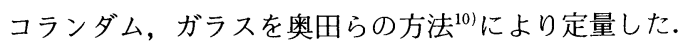
針状ムライトからなる多孔体を得るために, 焼成体を $4.6 \%$ のフッ化水素酸（以下 HF とする）中に入れて, $37^{\circ} \mathrm{C}$ で 2 48 時間処理しガラス相を溶出した. 


\section{2 多孔体の諸性状}

生成した針状ムライトの形態は，ガラス相を溶出した のち走査型電子顕微鏡（日本電子製，JXA-840 型）に より観察した，焼成体の相構造，ムライトの格子定数は 粉末法 X 線回折（理学電機製，RAD-2 B 型）で調へ， 格子定数は高純度微粉末 $\mathrm{Si}$ で回折角を補正したのち， （400），(311)，(041）線より算出した。また成長方向は 電子線回折（日本電子製，100-U 型）により調べた。 多孔体としての諸性状は，比表面積（BET 法）測定， 水銀圧入法（島津製作所製，水銀ポロシメーター，9310 型）による細孔分布，気孔率を測定して評価した．更に 見掛け密度は比重びん法により，20 $0^{\circ} \mathrm{C}$ の純水中で測定 した。

\section{3. 結果と考察}

\section{1 針状ムライトの生成に及ぼす反応条件の影響}

まず， $1300^{\circ} \sim 1700^{\circ} \mathrm{C}$ で 2 時間焼成して，針状ムライ 卜の生成に及ぼす焼成温度の影響を調べた，図 1 には $1550^{\circ}, 1600^{\circ}, 1650^{\circ}, 1700^{\circ} \mathrm{C}$ で焼成したのち, $\mathrm{HF}$ 中 で 24 時間処理した後のシート表面の形態を示す。また 表 1 には，図 1 より測定した針状結晶の長さ，太さ，ア スペクト比の結果を示す. $1550^{\circ} \mathrm{C}$ 以下ではムライトは 長さ $1 \mu \mathrm{m}$ 以下, 太さ $0.1 \sim 0.2 \mu \mathrm{m}$ の微結晶状態であり, まだ針状化はしていなかった。 $1550^{\circ} ， 1600^{\circ} \mathrm{C}$ では図 1
Table 1. Morphology of needle-like mullite from New Zealand kaolin fired at $1500^{\circ}-1700^{\circ} \mathrm{C}$ for $2 \mathrm{~h}$.

\begin{tabular}{cccc}
\hline $\begin{array}{c}\text { Temp. } \\
(\mathrm{C})\end{array}$ & $\begin{array}{c}\text { Length } \\
(\mu \mathrm{m})\end{array}$ & $\begin{array}{c}\text { Thickness } \\
(\mu \mathrm{m})\end{array}$ & $\begin{array}{c}\text { Aspect } \\
\text { ratio }\end{array}$ \\
\hline 1500 & $<1$ & $0.1-0.2$ & $<5$ \\
1550 & $0.5-5$ & $0.1-0.5$ & $5-10$ \\
1600 & $2-6$ & $0.2-0.6$ & $7-10$ \\
1650 & $10-20$ & $1.0-1.2$ & $10-15$ \\
1700 & $10-20$ & $1.0-1.8$ & $10-12$ \\
\hline
\end{tabular}

(a)，(b) のように長さ $1 \sim 6 \mu \mathrm{m}$, 太さ $0.1 \sim 0.5 \mu \mathrm{m}$ でアスペクト比が 5 10 の針状ムライトが密に生成し た。一方， $1650^{\circ} ， 1700^{\circ} \mathrm{C}$ になると， $1550^{\circ} ， 1600^{\circ} \mathrm{C}$ に 比べて生成密度は少なくなるものの，長さ $10 \sim 20 \mu \mathrm{m}$, 太さ 1 2 $\mu \mathrm{m}$ ，アスペクト比 10〜15（中には 20 以上の ものもある) で，断面が四角形の針状結晶の成長が促進 された。このように，針状化が進んだムライトを得るに は, ニュージーランドカオリンを原料とする場合, $1650^{\circ} \mathrm{C}$ の焼成温度が最適であることがわかった。また $1650^{\circ} \mathrm{C}$ で焼成時閒を種々変えても針状結晶の形態に変 化は認められなかった。

従来より陶磁器原料の陶土を $1200^{\circ} \sim 1300^{\circ} \mathrm{C}$ で焼成す ると, 素地中に長さ数 数十 $\mu \mathrm{m}$, 太さ $0.5 \sim$ 数 $\mu \mathrm{m}$ ほ どの針状ムライトが生成すると言われている ${ }^{6)}$ が, ニュージーランドカオリンを原料之する場合, $1500^{\circ} \mathrm{C}$
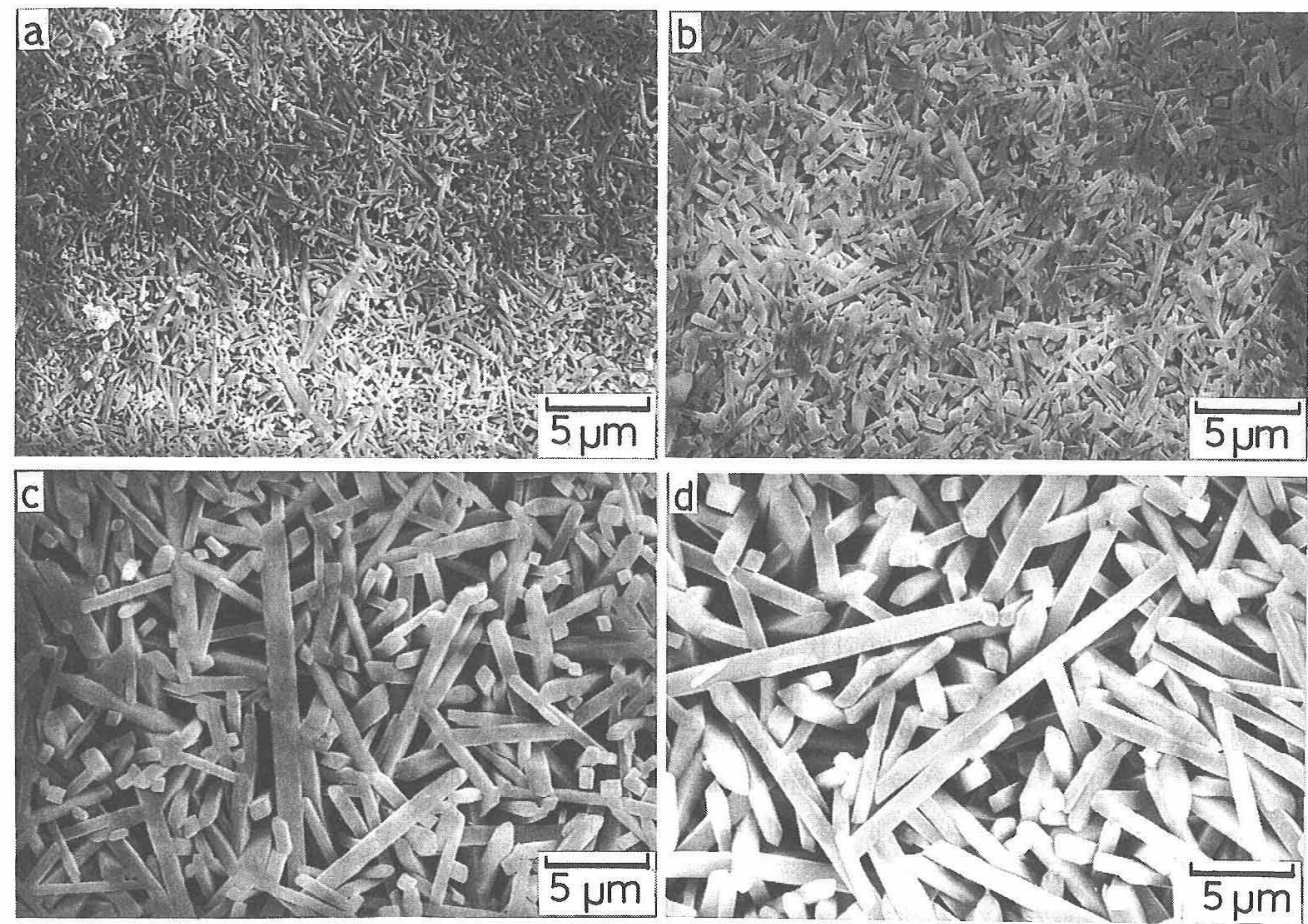

Fig. 1. SEM micrographs of needle-like mullite obtained from New Zealand kaolin. (a) $1550^{\circ} \mathrm{C}$, (b) $1600^{\circ} \mathrm{C}$, (c) $1650^{\circ} \mathrm{C}$ and (d) $1700^{\circ} \mathrm{C}$ 
以下で針状結晶の成長は認められなかった。陶磁器の原 料(例えば天草陶土等) は，通常 $\mathrm{SiO}_{2}$ を $80 \sim 85 \mathrm{wt} \%$ 含有し，また $\mathrm{K}_{2} \mathrm{O}, \mathrm{Na}_{2} \mathrm{O}$ が $2 \sim 4 \mathrm{wt} \%$ 共存しているの で $1300^{\circ} \mathrm{C}$ 以上になるとガラス相は溶融しやすくなり, 液相存在下でムライト結晶の成長が促進される。一方, 用いたニュージーランドカオリンは $\mathrm{SiO}_{2}$ の含有量が 52 wt $\%$ と低く,しかも $\mathrm{K}_{2} \mathrm{O}, \mathrm{Na}_{2} \mathrm{O}$ は $0.1 \mathrm{wt} \%$ 以下である. 陶土とニュージーランドカオリンでは, 以上のように針 状ムライトの生成温度領域が異なったが, これは液相成 分又はその量が異なるため, 生成した液相へのムライト の溶解度等が異なり, 結晶の成長速度に差が生じたこと によるものと推察される.したがって,次に $1300^{\circ}, 1550^{\circ}$, $1600^{\circ}, 1650^{\circ}, 1700^{\circ} \mathrm{C}$ でそれぞれ 2 時間焼成した二ュー ジーランドカオリンの相構造の変化をX 線回折により 調べた。回折図形を図 2 に示す. $1300^{\circ} \mathrm{C}$ ではムライト,

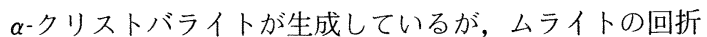
強度は小さくムライト化はあまり進んでいない。 $1550^{\circ} \mathrm{C}$ になるとムライトの生成は増加しているが， $\alpha$ クリストバライトの回折強度は更に大きくなりマトリッ クスの結晶化が進んでいることがわかる。ところが $1600^{\circ} \mathrm{C}$ 以上では， $\alpha$-クリストバライトは溶融してしま いピークはブロードになった. $1600^{\circ} \mathrm{C}$ 以上で針状ムラ イトの成長が促進された理由はまだ明らかでないが，マ トリックスの溶融ガラス相がより低粘性の液相となるこ とにより $\mathrm{SiO}_{2}$ と $\mathrm{Al}_{2} \mathrm{O}_{3}$ の反応性が増すとともに, マト リックス中でのムライト結晶の成長速度が大きくなるの で, 結晶成長が起こりやすくなっているものと推察され る.

次に， $1500^{\circ} \sim 1700^{\circ} \mathrm{C}$ で焼成したままの試料中のムラ イト，コランダム，ガラス量を HF に対するそれぞれ の溶解度を考慮して調べた結果を表 2 に示す．焼成温度 が高くなるに従いコランダム，ガラス量は減少し，ムラ イト化が促進されていることがわかる. $1650^{\circ}, 1700^{\circ} \mathrm{C}$ でムライト量は59 60 wt\% であるが,これは二ュー

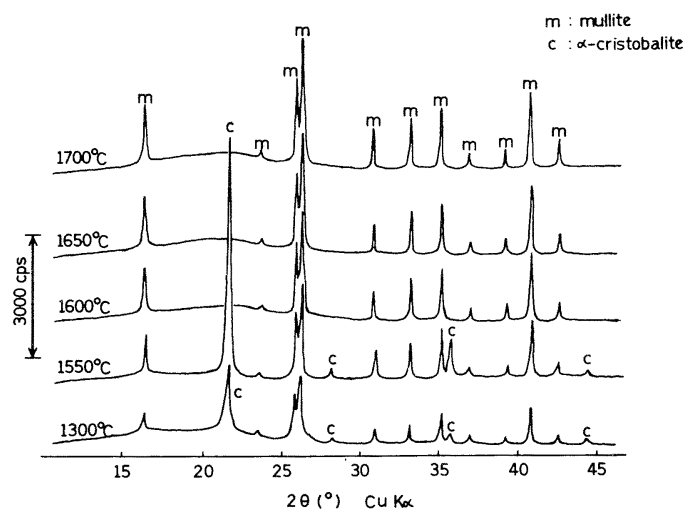

Fig. 2. X-ray diffraction patterns of New Zealand kaolin fired at $1300^{\circ}-1700^{\circ} \mathrm{C}$ for $2 \mathrm{~h}$.
Table 2. The amount of mullite, corundum and glass in New Zealand kaolin fired at $1500^{\circ}-1700^{\circ} \mathrm{C}$ for $2 \mathrm{~h}$.

\begin{tabular}{cccc}
\hline $\begin{array}{c}\text { Growth } \\
\text { temp }\left({ }^{\circ} \mathrm{C}\right)\end{array}$ & $\begin{array}{c}\text { Mullite } \\
\text { (wt\%) }\end{array}$ & $\begin{array}{c}\text { Corundum } \\
\text { (wt\%) }\end{array}$ & $\begin{array}{c}\text { Glass } \\
\text { (wt\%) }\end{array}$ \\
\hline 1500 & 48.02 & 3.33 & 48.68 \\
1550 & 53.69 & 1.89 & 44.42 \\
1600 & 56.80 & 1.54 & 41.66 \\
1650 & 60.04 & 0.68 & 39.28 \\
1700 & 59.14 & 0.71 & 40.15 \\
\hline
\end{tabular}

ジーランドカオリン中のアルミナ成分がすべてムライト 化した場合の理論ムライト化率（約 58\%）とほぼ一致 する。また， $1650^{\circ} \mathrm{C}$ 以上でコランダム量は約 $0.7 \mathrm{wt} \%$ で，更に図 2 でコランダムの回折ピークが認められな かったことより，原料中のアルミナ成分はほとんどムラ イト化しているもの之推察される.

\section{2 針状組織からなる多孔体の生成とその特性}

まず押し出しシートを $1650^{\circ} \mathrm{C} て ゙ 2$ 時間焼成したの 5, HF 中で 2 48 時間処理し, ガラス溶出量, 多孔体 の $\mathrm{Al}_{2} \mathrm{O}_{3} / \mathrm{SiO}_{2}$ 比 (モル比), 見掛け密度に及ぼす処理 時間の影響を調べた。結果を図 3 に，また $20 ， 48$ 時間 処理して得た多孔体の破面の状態を図 4 に示す。ガラス 相は 20，48 時間処理することにより，それぞれ 42〜44, 52 53 wt\% 溶出した. 原料中のアルミナ成分は表 2 の 結果より，ほぼムライト化していたので理論的には約 $42 \mathrm{wt} \%$ のガラス相が HF により溶出できる. 図 3 より, 20 時間以上処理すると理論溶出量よりも過剩にガラス 相が溶出したことになるが，この場合，多孔体の見掛け 密度は $2.96 \sim 2.97 \mathrm{~g} / \mathrm{cc}, \mathrm{Al}_{2} \mathrm{O}_{3} / \mathrm{SiO}_{2}$ 比は $0.88 \sim 0.89$ であったのでガラス相は十分に溶出していないことがわ かる. 24 時間の処理では, 多孔体の表面にはガラス相

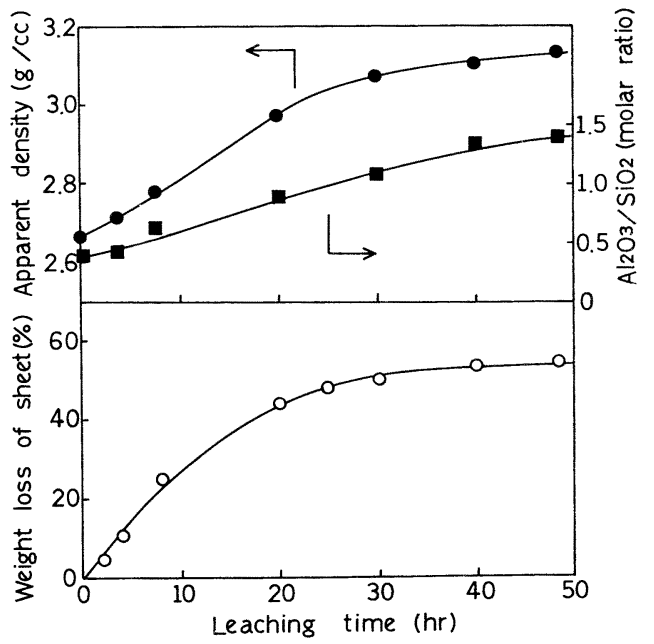

Fig. 3. Effect of leaching time on the weight loss, the apparent density and the chemical composition of porous sheets. 
は認められなかったが，内部には図 4 (a)，(b) のよう にまだ明らかに残存していることがわかる。一方，ガラ ス相が理論量よりも過剩に溶出した 48 時間の処理では, 見掛け密度 $3.13 \sim 3.14 \mathrm{~g} / \mathrm{cc}, \mathrm{Al}_{2} \mathrm{O}_{3} / \mathrm{SiO}_{2}$ 比 $1.47 \sim$ 1.48 の理論ムライトに近い多孔体が得られた. またこ の試料では，図 4 (c), (d) のように多孔体の内部にガ ラス相が全く認められず，また結晶は先細りでかつ幅が 狭くなった．このように，長時間の HF 処理によりム ライトも溶出したものと考えられる。この場合，ムライ
トの組成は $\mathrm{SiO}_{2}: 28.33, \mathrm{Al}_{2} \mathrm{O}_{3}: 71.27, \mathrm{Fe}_{2} \mathrm{O}_{3}: 0.23$, $\mathrm{TiO}_{2}: 0.05, \mathrm{CaO}: \mathrm{Tr}, \mathrm{MgO}: \mathrm{Tr}, \mathrm{Na}_{2} \mathrm{O}: 0.05$ wt\%, $\mathrm{K}_{2} \mathrm{O}$ : Tr であり $\mathrm{CaO}, \mathrm{MgO}, \mathrm{Na}_{2} \mathrm{O}, \mathrm{K}_{2} \mathrm{O}$ はそれぞれ 原料の場合よりも低下した。一方， $\mathrm{Fe}_{2} \mathrm{O}_{3}, \mathrm{TiO}_{2}$ の含 有量は HF 処理によってもほとんど変わらなかったが,

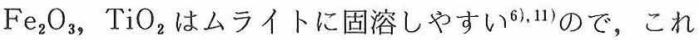
らは針状ムライトに固溶しているものと考えられる。し かし，48 時間処理して得たムライトの格子定数を X 線 回折により調べた結果, $a_{0}=7.568, b_{0}=7.689, c_{0}=$
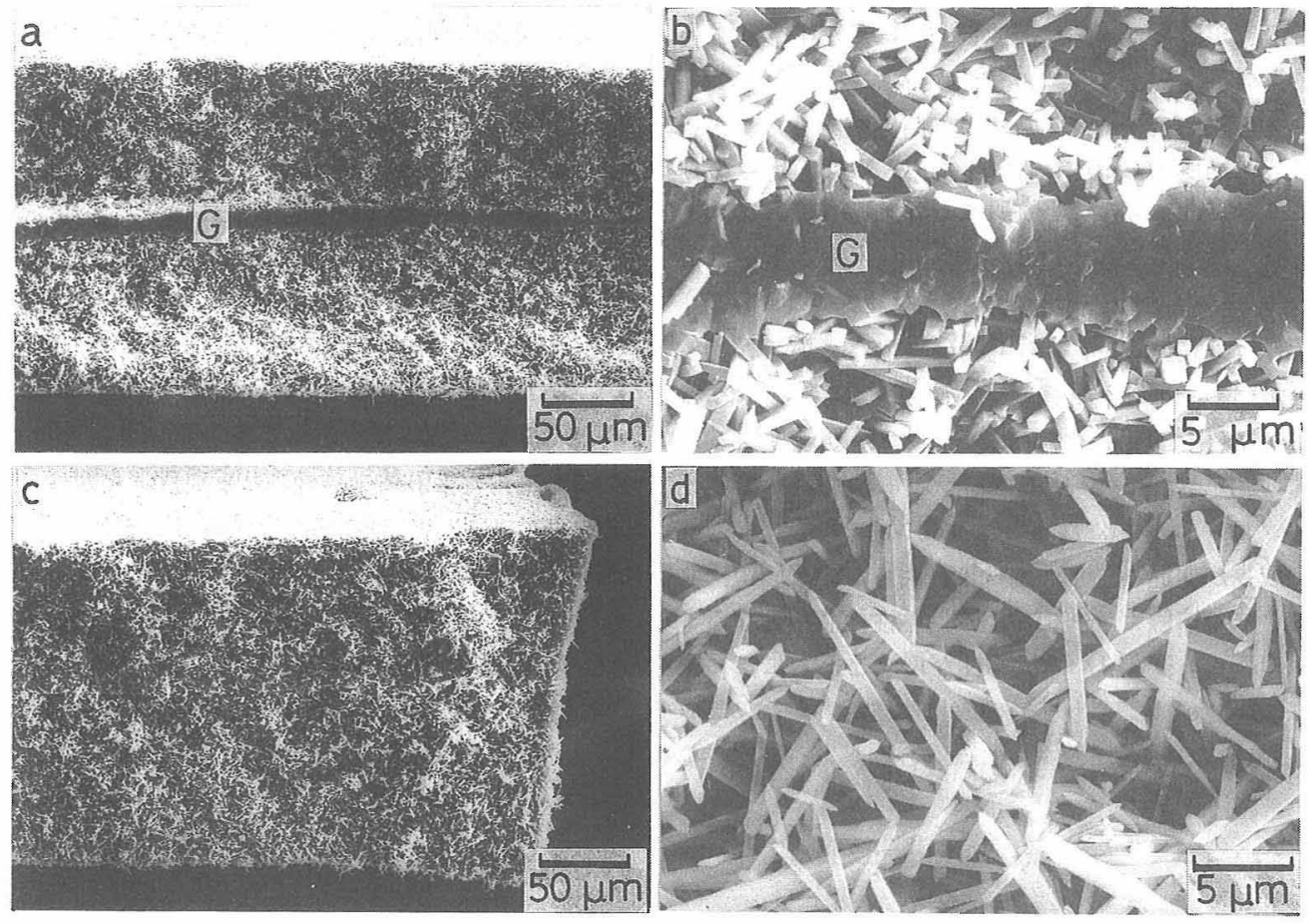

Fig. 4. SEM micrographs of the fracture surface of porous sheets composed of needle-like mullite. $\mathrm{G}:$ unleached glass
(a), (b) : $20 \mathrm{~h}$ and (c), (d) : $48 \mathrm{~h}$
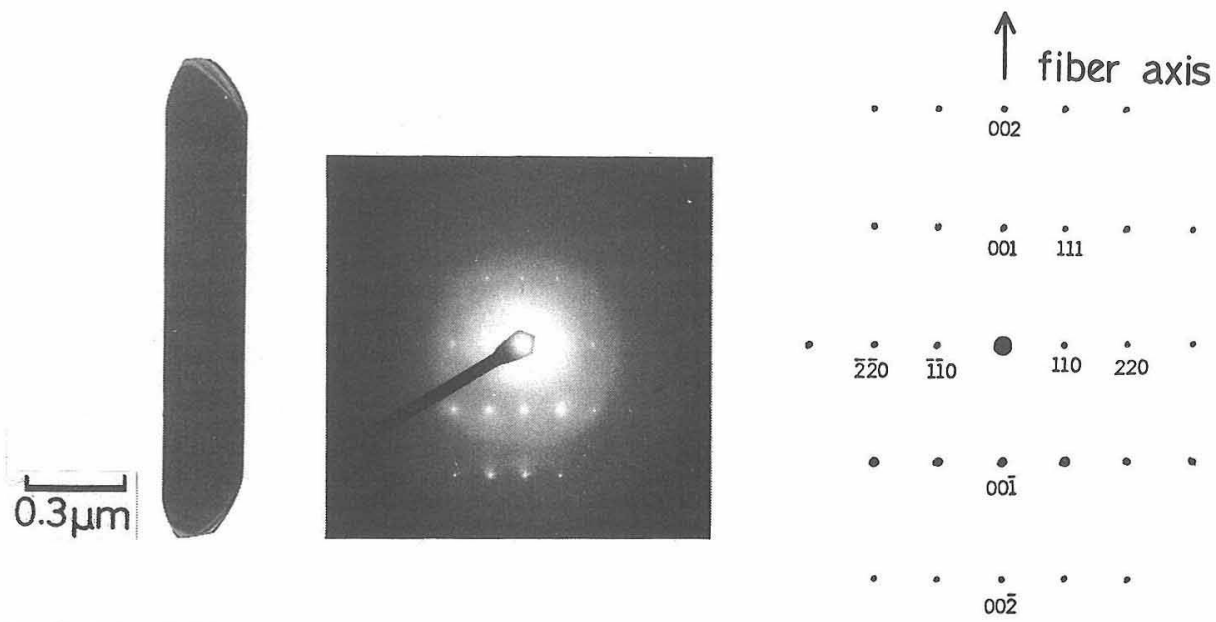

Fig.5. Bright field image and electron diffraction pattern of a needle-like mullite obtained at $1650^{\circ} \mathrm{C}$. 
$2.889 \AA$ 无あ゙り, $\mathrm{Fe}_{2} \mathrm{O}_{3}, \mathrm{TiO}_{2}$ の固溶効果は認められな かった。

図 5 には，ガラス相を十分に除去した針状ムライトの 透過電子顕微鏡像亡その電子線回折パターンを示す．針 状結晶の成長方向は [001] であったが,これはアルミナ, シリカを原料として Czochralski 法等 ${ }^{12) ~ 14)}$ によって得 られたムライト単結晶の成長方向と一致した。しかし, キセロゲルの熱処理によって得られたムライトウイス カ一の成長方向 ${ }^{4)}$ とは異なった.

次に，針状組織を有するムライトの多孔体としての特 性を調べるために，ガラス相を 10.9，20.1，39.3 wt\% 溶出して細孔分布，気孔率を測定した。まず図 6 にはガ ラス相を 10.9, 39.3 wt\% 溶出した試料の細孔分布を, また図 7 には各試料の気孔率と溶出量の結果を示す. 比 較のために焼成したままの試料の結果も示す，細孔径は ビの試料でも約 $0.5 \sim 0.6 \mu \mathrm{m}$ であり，均一な細孔が存 在していることがわかる，一方，気孔率はガラス相の溶 出量にほぼ比例して増加しており，ガラス相が内部まで 約 39.3 wt \% 溶出した場合には，気孔率約 $60 \%$ の多孔 体が得られた。

以上の上うに細孔径が均一なムライト多孔体が得られ

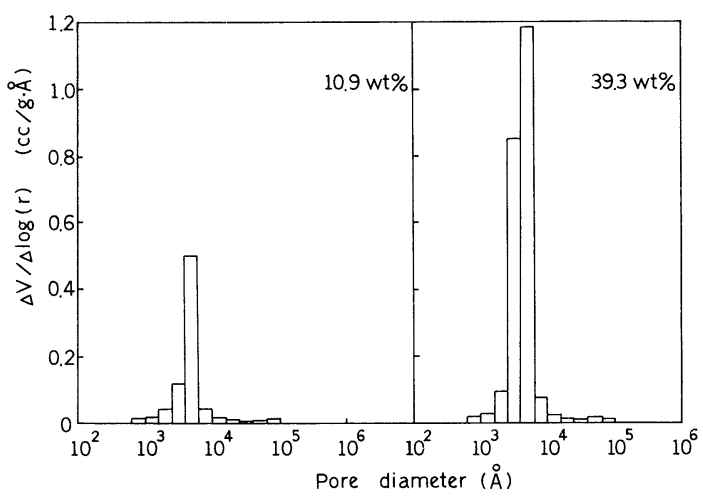

Fig. 6. Pore size distribution of sheets leached out 10.9 and $39.3 \mathrm{wt} \%$ of glass.

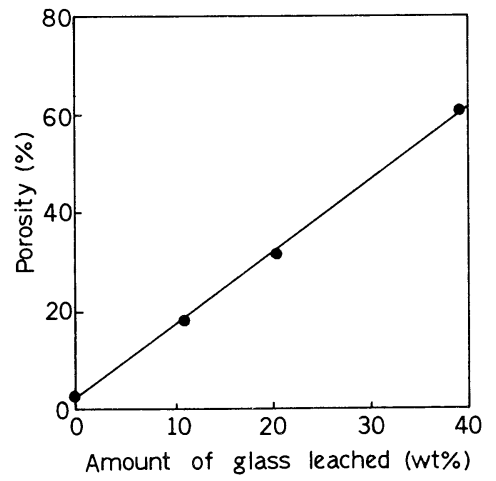

Fig. 7. Relation between the porosity of sheet and the amount of glass leached.

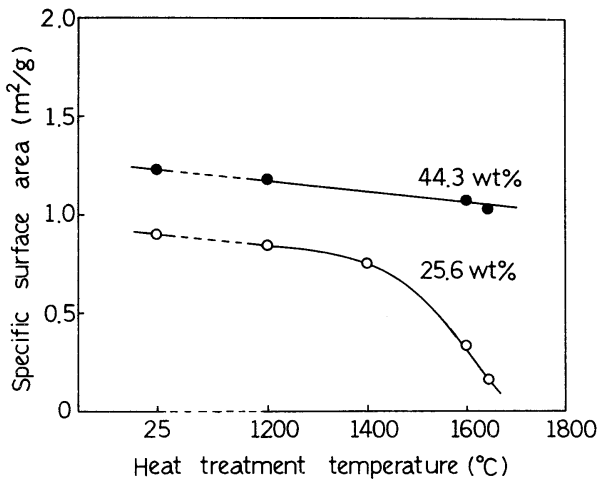

Fig. 8. The change of the specific surface area of porous sheets by reheat treatment at $1200^{\circ}-1650^{\circ} \mathrm{C}$ for $2 \mathrm{~h}$.

たが，ガラス含有率が少ないムライトは高温まで安定で あることが期待される. したがって次に，ガラス相を $25.6 ４ 4.3 \mathrm{wt} \%$ 溶出した多孔体を空気中で $1200^{\circ}$, $1400^{\circ}, 1600^{\circ}, 1650^{\circ} \mathrm{C}$ でそれぞれ 2 時間再加熱し, 比 表面積の変化を調べた．結果を図 8 に示す。ガラス相の 溶出量が多いほよ゙，気孔率が増すので比表面積は高くな る傾向を示した，溶出量が 25.6 wt \% の場合，高温で再 加熱するほど比表面積は減少し, $1600^{\circ} \mathrm{C}$ 以上では著し く低下した。これは図 2 で示したように， $1600^{\circ} \mathrm{C}$ 以上 ではガラス相が溶融しやすくなるので，多孔体内部に残 存するガラス相が表面に溶け出し，気孔をふさいだこと によるものであろう。一方，ガラス相を $44.3 \mathrm{wt} \%$ 溶出 すると $1600^{\circ} \mathrm{C}$ 以上でも比表面積の低下は認められず, 高温でも安定なムライト多孔体であることがわかった。

以上のように，本研究で得られた針状ムライトからな る多孔体の比表面積は，まだ高々 $1 \mathrm{~m}^{2} / \mathrm{g}$ であったが針 状結晶の成長条件を更に検討し，微細な針状結晶が生成 すれば，より高比表面積を有するムライト多孔体が得ら れるものと期待される.

\section{4. 総 括}

本研究では, 安価でしかも不純物含有量が少ない ニュージーランドカオリンを原料とし，針状ムライトの 生成条件，またガラス相の溶出によって得られる針状組 織からなるムライト多孔体の調製条件及びその特性につ いて調べ，以下の結果を得た。

（1）針状ムライトは $1550^{\circ} \mathrm{C}$ より成長し，マトリッ クスの溶融ガラス相がより低粘性の液相となる $1650^{\circ} \mathrm{C}$ 以上では, 長さ $10 \sim 20 \mu \mathrm{m}$, 太さ $1 \sim 2 \mu \mathrm{m}$ で, [001] 方 向に成長した針状結晶が密に交錯して得られた。また $1650^{\circ} \mathrm{C}$ 以上では，原料中のアルミナ成分はほとんどム ライト化しており，その組成はムライト 59 ～60, ガラ ス 39〜40, コランダム約 $0.7 \mathrm{wt} \%$ であった.

(2) $1650^{\circ} \mathrm{C}$ で焼成したのち $\mathrm{HF}$ 中でガラス相を 
$39.3 \mathrm{wt} \%$ 溶出すると, 細孔径が $0.5 \sim 0.6 \mu \mathrm{m}$, 気孔率 が約 $60 \%$ の針状組織を有するムライト多孔体が生成し た。またガラス相の溶出とともに比表面積も増加した が，ガラス相を十分に溶出した多孔体を $1200^{\circ} \sim 1650^{\circ} \mathrm{C}$ で再加熱しても比表面積は低下せず, 高温でも安定で あった. 更に, この場合, 多孔体の組成, 密度は理論么 ライトに近く, $\mathrm{Fe}_{2} \mathrm{O}_{3}, \mathrm{TiO}_{2}$ を約 $0.28 \mathrm{wt} \%$ 固溶してい るもののアルカリ含有量は低いことがわかった.

謝辞 本研究の透過電子顕微鏡観察及び比表面積の測定 は, 長崎大学工学部教授 - 江頭 誠先生, 助教授・清水康博先 生の御好意によりました。ここに深く感謝致します。

\section{文献}

1) E.I. DuPont de Nemours \& Co., U.S.A. Pat. 3, 104, 943 (1960).

2）鈴木松郎, 平石俊一, 吉村昌弘, 宗宮重行, 日化, 1984, No. 6, 792-99.
3）山口敏秀, 鈴木松郎, 平石俊一, 吉村昌弘, 宗宮重行, 窯協 93, 101-04 (1985).

4) 岡田 清, 大津賀 望, 第 26 回窯業基礎討論会講演要旨 集 (1988) p. 197

5) N. L. Bowen and J.W. Greig, J. Am. Ceram. Soc., 7. 238-54 (1924).

6）浜野健也, “窯業の研究 II ”, 山内俊吉編, 技報堂（1961） pp. 301-34.

7）吉木文平, “鉱物工学”, 技報堂 (1967) pp. 392-94.

8）奥田 博, “無機合成材料とその応用”, 田賀井秀夫編, 化学工業社, 別冊化学工業, 第 14 巻, 第 6 号 (1970) pp. 219-39.

9）河波利夫，“新素材シリーズ・ムライト”, 宗宮重行編, 内田老鶴围 (1985) pp. 123-35.

10）奥田 博, 羽賀 満, 名工技試報告, 4, 510-14 (1955).

11) M. K. Murthy and F. A. Hummel, J. Am. Ceram. Soc., 43, 267-73 (1960).

12) W. Guse and D. Mateika, J. Cryst. Growth, 22, 237-40 (1974).

13) W. Guse, J. Cryst. Growth, 26, 151-52 (1974).

14) D. Michel, L. Mazerolles and R. Portier, 1st. Int. Workshop on Mullite Abst., Tokyo (1987) p. 51. 